\title{
FAKE NEWS IN THE MALAYSIAN 14TH GENERAL ELECTION: SHALL THE NET BE FREE FOREVER?*
}

\author{
Mahyuddin Daud**
}

\begin{abstract}
Malaysia had its $14^{\text {th }}$ General Election on $9^{\text {th }}$ May 2018 that resulted in a change of government from the Barisan Nasional (BN) who ruled since 1957's independence to the Pakatan Harapan (PH) coalition. Acknowledging the power that social media had in influencing voters, The Communications and Multimedia Act 1998 (CMA) was mobilised to hunt dissenters, where some cases resulted in successful prosecution. Despite the drastic move taken to enact the Anti-Fake News Act 2018 one month before the election, the previous government failed to convince the public that fake news was grave threats to society. Instead, the above initiative may have contributed to BN's painful defeat against the inexperienced PH. After the election, $\mathrm{PH}$ faced similar issues of having to deal with a plethora of fake news online and the 'gun' had now turned towards them. The PH Ministers had difficult times correcting misstatements issued through social media which was flooded with sarcastic trolls, some of which may amount to illegal content. Through a qualitative method, this article assesses how social media influenced the landscape of $14^{\text {th }} \mathrm{GE}$. Consequently, international and national legal frameworks have been developed to combat the dissemination of fake news online, as analysed in the second part of this paper. The third part further examines how popular social media platforms provide countermeasures in dealing with fake news and how far legal frameworks correspond to the practices of service providers. It is hypothesised that in time, the PH coalition should have turned towards censoring the internet as done by the previous $\mathrm{BN}$ government due to the emerging threat of online fake news all over the world.
\end{abstract}

Keywords: online fake news, social media, online illegal content, disinformation.

* This paper is funded by the Ministry of Higher Education Malaysia and International Islamic University Malaysia (IIUM) under the Fundamental Research Grant Scheme (FRGS17-018-0584) and IIUM Research Acculturation Grant Scheme (IRAGS18-011-0012).

** Assistant Professor Ahmad Ibrahim Kulliyyah of Laws, International Islamic University Malaysia. Email: mahyuddin@iium.edu.my. 


\title{
BERITA PALSU DALAM PILIHANRAYA UMUM KE-14 MALAYSIA: MUNGKINKAH INTERNET BEBAS SELAMANYA?
}

\begin{abstract}
ABSTRAK
Malaysia telah mengadakan Pilihan Raya Umum Ke-14 (PRK14) pada 9 Mei 2018 yang menyaksikan perubahan kerajaan dari Barisan Nasional (BN) yang memerintah sejak kemerdekaan kepada Pakatan Harapan (PH). Menyedari pengaruh media sosial yang kuat terhadap pengundi, Akta Komunikasi dan Multimedia 1998 telah digerakkan untuk mendakwa orang yang menentang kerajaan yang mana terdapat beberapa kes pendakwaan yang berjaya. Walaupun langkah drastik telah diambil untuk menggubal Akta Anti-Palsu 2018 sebulan sebelum pilihan raya, kerajaan sebelumnya gagal untuk meyakinkan orangramai bahawa berita palsu adalah ancaman serius kepada masyarakat. Tetapi sebaliknya, inisiatif di atas mungkin menyumbang kepada kekalahan BN kepada PH yang tidak berpengalaman. Selepas pilihan raya, $\mathrm{PH}$ dilihat menghadapi masalah yang sama mengenai kebanjiran berita palsu dalam talian, dan 'pistol' telah ditujukan kepada mereka. Menteri-menteri PH berhadapan dengan kesukaran besar untuk membetulkan kenyataan yang terpesong melalui media sosial. Media sosial dibanjiri dengan troll sarkastik, yang mana di antaranya mungkin mengandungi kandungan yang dilarang. Melalui kaedah kualitatif, kertas ini bermula dengan penilaian bagaimana media sosial telah mempengaruhi landskap PRK14. Rangka kerja undang-undang antarabangsa dan kebangsaan telah turut dibangunkan untuk memerangi penyebaran berita palsu dalam talian, seperti yang dianalisa di bahagian kedua makalah ini. Bahagian ketiga menganalisa bagaimana platfom media sosial yang popular mengurus isu berita palsu sebagai tindak balas dan sejauh mana kerangka undang-undang bertindak-balas dengan amalan penyedia perkhidmatan. Adalah menjadi hipotesis bahawa dengan keadaan ini, PH seharusnya bertukar arah dari menyokong kebebasan internet sepenuhnya kepada penyekat internet seperti yang dilakukan oleh kerajaan BN terdahulu kerana timbulnya ancaman berita palsu dalam talian di merata dunia.
\end{abstract}

Kata Kunci: berita palsu dalam talian, media sosial, kandungan terlarang dalam talian, maklumat palsu. 


\section{INTRODUCTION}

Malaysia held its $14^{\text {th }}$ General Election to elect members of the Dewan Rakyat (Lower House) and the Dewan Undangan Negeri (State Legislative Assemblies). As a country that embraces the spirit of parliamentary democracy and a constitutional monarchy, Malaysia's general elections provide opportunities for its citizens to play active roles in charting the country's future. Before the $14^{\text {th }}$ General Election, many have expected that the social media will once again become the deciding influence for the electoral outcome. In the $2008 \mathrm{GE}$, the opposition had shifted its political strategy to use social media for their election campaigns in response to the ruling government's control of screening time in the mainstream media (such as televisions and radio stations). Such action was not shocking considering that during the previous $12^{\text {th }}$ and $13^{\text {th }}$ general elections, social media had played its card well that significantly reduced the ruling government's two-third seats in the Parliament. ${ }^{1}$

In response to the political approach taken by the opposition, the ruling government in the $2013^{\text {th }} \mathrm{GE}$ had started to put more attention to social media campaigning. ${ }^{2}$ More content-was aired through online video, published through popular social media sites including Facebook, Twitter, and YouTube. Although the focus was geared towards social media, mainstream media was still relevant for election campaigns but restricted to BN-related campaigns only.

Acknowledging the power that social media had in influencing voters, the Communications and Multimedia Act 1998 (CMA) was mobilised to hunt dissenters, where some cases have resulted in successful prosecution. Despite the drastic move to enact the Anti-Fake News 2018 one month before the $14^{\text {th }} \mathrm{GE}$, the previous government had failed to convince the public that fake news was a grave threat to society. On this note, Freedom House has recorded

\footnotetext{
James Gomez, "Social Media Impact on Malaysia's 13th General Election," Asia Pacific Media Educator, 2014, https://doi.org/10.1177/1326365X14539213.

2 Mohd Azizuddin Mohd Sani, "The Social Media Election in Malaysia: The 13th General Election in 2013," Kajian Malaysia 32, no. 2 (2014): 123-147.
} 
several activities that to its conclusion, have greatly affected Malaysia's internet freedom in the long run. ${ }^{3}$

\section{COMBATING FAKE NEWS: HOW SERIOUS IS THE PROBLEM?}

When the Anti-Fake News Act 2018 was introduced on $11^{\text {th }}$ April 2018 , about one month before the $14^{\text {th }}$ GE, the first subject was a Danish national, Salah Salem Saleh Sulaiman, who was fined RM10,000 (US\$2,500). He posted a video on YouTube accusing the "police of taking 50 minutes to respond to the shooting of a Palestinian lecturer in Kuala Lumpur" on $21^{\text {st }}$ April 2018. In response to the allegation, the police said that "they took eight minutes to respond to the incident". Sulaiman was charged for publishing fake news with ill intent through a YouTube video. Sulaiman had failed to pay the fine and opted for one-month imprisonment. ${ }^{4}$

Meanwhile, in another instance, Fahmi Reza, an activist and graphic designer was charged under Section 233 of the CMA 1998 for publishing a caricature mocking the former Prime Minister, Datuk Seri Najib Razak. He was tried and found guilty by the Sessions Court, which sentenced him to one-month imprisonment and RM30, 000 fine. Fahmi however managed to conduct an online crowdfunding to pay for the fine within the duration of 18 hours and was granted a stay pending an appeal to the High Court. ${ }^{5}$

In another case concerning an online news portal, Malaysiakini, two of its directors were arrested and charged under

3 Freedom House, "Malaysia Country Report | Freedom on the Net 2018," Freedom House, 2018, https://freedomhouse.org/report/freedomnet/2018/malaysia. Freedom House is a U.S.-based, U.S. governmentfunded non-profit non-governmental organization that conducts research and advocacy on democracy, political freedom, and human rights.

4 Qishin Tariq, "Danish National First to Be Sentenced under Anti-Fake News Law," The Star Online, 2018, https://www.thestar.com.my/news/nation/2018/04/30/danish-nationalfirst-to-be-sentenced-under-anti-fake-news-law/.

5 Amanda Yeap, "Fahmi Reza Jailed One Month, Fined RM30,000 over Offensive Caricature of PM - Nation | The Star Online," The Star, 2018, https://www.thestar.com.my/news/nation/2018/02/20/fahmi-reza-getsone-month-jail-fined-rm30000-over-offensive-caricature-of-pm/. 
Sections 233 and 244 of the CMA 1998 for improper network use. In July 2016, the directors, Gan and Premesh were slapped with the said charges for publishing on their website a "video clip of a press conference held by Datuk Khairuddin Abu Hassan titled, "Khairuddin: Apandi Ali is not fit to be AG and he should quit immediately". It was published both in English and Bahasa Malaysia. ${ }^{6}$ However, in September 2018, the Malaysian Communications and Multimedia Commission withdrew the charges. There had been several other incidents where members of the media have been threatened with legal suits for allegedly defaming former country leaders and these incidents have caused 'chilling effects' in media freedom. ${ }^{7}$

The opposition continued to rely on social media and private internet television channels for their campaigns. Eventually, the young and inexperienced $\mathrm{PH}$ coalition managed to dethrone $\mathrm{BN}$, resulting in unprecedented and painful defeat. After the election, it was noted that $\mathrm{PH}$ as the new government faced similar issues with a plethora of fake news online, and this time, the 'gun' was aimed towards them. ${ }^{8}$ The PH Ministers had difficulties in correcting misstatements issued through social media. As a result, social media

6 Debra Chong, "Court Acquits Malaysiakini Bosses over Airing Video against Ex-AG Apandi | Malaysia | Malay Mail,” Malay Mail, 2018, https://www.malaymail.com/news/malaysia/2018/09/20/court-acquitsmalaysiakini-bosses-over-airing-video-against-ex-ag-apandi/1674558.

7 Committee for Information Computer and Communications Policy of OECD, "The Role of Internet Intermediaries in Advancing Public Policy Objectives" (Paris, 2011), www.oecd.org/dataoecd/8/59/45997042.pdf.

8 "Pakatan on Offensive over 'fake News' | The Malaysian Insight," accessed August 18, 2020, https:/www.themalaysianinsight.com/s/194010; "Politics and Policy: Fighting Fake News without an Anti-Fake News Law | The Edge Markets," accessed August 18, 2020, https://www.theedgemarkets.com/article/politics-and-policy-fightingfake-news-without-antifake-news-law; "Harapan Has Lost the Social Media Advantage, Says DAP Man," accessed August 18, 2020, https:/www.malaysiakini.com/news/511093; "Pakatan Hopes Media Will Continue to Be Fair, and Not Report Fake News | Malaysia | Malay Mail," accessed August 18, 2020, https://www.malaymail.com/news/malaysia/2020/03/15/pakatan-hopesmedia-will-continue-to-be-fair-and-not-report-fake-news/1846792. 
was flooded with sarcastic trolls, some of which may amount to illegal content. ${ }^{9}$

There has yet to be any research done (as of the date this article was written) to confirm whether social media was a key factor that influenced the $14^{\text {th }} \mathrm{GE}$ results. However, a few incidents occurred were dissenters, and publishers of fake articles were arrested and investigated by the MCMC and police. ${ }^{10}$ Two months before the GE14 election, the Anti-Fake News Act 2018 was hastily passed by the Parliament, where some alleged that this was another move to tighten up internet censorship and chill freedom of expression. ${ }^{11}$ However, the results of GE14 had defied all wild speculations in the social media predicting that it would be the dirtiest Malaysian GE in history, as eventually none of them were found to be true. ${ }^{12}$ Nevertheless, the arrests and investigations made by MCMC and the police had somewhat negatively affected Malaysia's Freedom on the Net Index, where international human rights organisations and watchdogs had heavily criticised the then ruling government on such moves. ${ }^{13}$

A 10-year study was conducted by Syed Arabi Idid on media use and trust among party supporters from 2008 to 2018. According

9 “ Pakatan on Offensive over 'fake News' | The Malaysian Insight."

10 Mahyuddin Daud and Sonny Zulhuda, "Dissemination of False Content Online in Malaysia: A Legal Update," 7th International Conference on Law And Society (ICLAS 7), 2018.

11 Marc Lourdes, "Malaysia's Anti-Fake News Law Raises Media Censorship Fears," CNN, 2018, https://edition.cnn.com/2018/03/30/asia/malaysia-anti-fake-news-billintl/index.html; ARTICLE 19, "Malaysia: Anti-Fake News Act Should Be Repealed in Its Entirety," ARTICLE 19, 2018, https://www.article19.org/resources/malaysia-anti-fake-news-actrepealed-entirety/.

12 M. Moniruzzaman and Kazi Fahmida Farzana, "Malaysia' 14th General Election: End of an Epoch, and Beginning of a New?," Intellectual Discourse 26 (2018).

13 Freedom House, "Freedom on the Net 2016 Country Profile: Malaysia," 2016, https://freedomhouse.org/report/freedom-net/2016/malaysia; Freedom House, "Freedom on the Net 2017: Country Profile," Freedom House, 2017, https://freedomhouse.org/report/freedomnet/2017/malaysia; Freedom House, "Malaysia Country Report | Freedom on the Net 2018," Freedom House, 2018. 
to the study, as far as the pre 2008 was concerned, traditional media was still very much in use. Before 2008, the majority of the political parties did not own any social media account except for Anwar Ibrahim who owned a Twitter account before that year. ${ }^{14}$ However, traditional media (such as television, radio, print newspaper) continued to be censored by BN, despite the non-censorship policies and rules found in the MSC Bill of Guarantee and Section 3 of the Communications and Multimedia Act 1998. Hence, Syed's study indicated that over the past 10 years, people have turned to the internet to voice their concerns through mediums such as social media and blogs. ${ }^{15}$

It was observed that when internet access began to expand in the early 2000s, the Parliament was worried that it may become a host for illegal content from abroad, such as pornography. ${ }^{16}$ Hence, the Parliament decided to establish an internet regulator, namely the Malaysian Communications and Multimedia Commission. They are armed with the CMA 1998 to ensure that no illegal content shall be published in Malaysia. To supplement this piece of legislation, an industry self-regulated Content Code was developed in 2004 that provides guidelines for the communications and multimedia industry in relation to internet content regulation. ${ }^{17}$ As of 2018, another layer of legislative teeth was added, namely the Anti-Fake News Act 2018 that criminalises the publication of fake news, both online and offline.

It is also noteworthy that similar development can also be traced globally, where international legal instruments, namely the United Nations Joint Declaration on Freedom of Expression and 'Fake News', Disinformation and Propaganda has been developed in an attempt to address the problem, as discussed below.

\footnotetext{
14 Gomez, "Social Media Impact on Malaysia's 13th General Election."

15 Syed Arabi Idid, "The Malaysian 14th General Election: Media Use and Trust Among Party Supporters" (Kuala Lumpur, 2018).

16 Parliament of Malaysia, "Penyata Rasmi Parlimen" (Kuala Lumpur, 1998).

17 Mahyuddin Daud, Internet Content Regulation (Kuala Lumpur: IIUM Press, 2019).
} 


\section{COMBATING FAKE NEWS AT THE GLOBAL SETTING}

Fake news and disinformation have become a worldwide 'cancer' for many nations. One notable example is how fake images about the Rohingya conflict were used as propaganda by the Burmese officials to cover up the actual tragedy happening in the Rakhine state. ${ }^{18}$ It is interesting to note that because the problem of fake news is now happening on a global scale, the United Nations took an action to call relevant stakeholders for engagements and consultations on the matter.

As a result, the United Nations Joint Declaration on Freedom of Expression and 'Fake News', Disinformation and Propaganda (herein 'the Joint Declaration') was adopted by the United Nations Special Rapporteur on Freedom of Opinion and Expression on $3^{\text {rd }}$ March 2017. This took place after a series of consultations were made with the Organization for Security and Co-operation in Europe Representative on Freedom of the Media, the Organization of American States (OAS) Special Rapporteur on Freedom of Expression, and the African Commission on Human and Peoples' Rights Special Rapporteur on Freedom of Expression and Access to Information. Stakeholders that took part in the discussion include a British non-profit human rights organisation - ARTICLE 19, and the Centre for Law and Democracy.

Article 1(a) of the Joint Declaration, in its General Principles, provides that any restriction on the right to freedom of expression must comply with the strict tests provided in the International Covenant on Civil and Political Rights (ICCPR) and relevant principles of international law. ${ }^{19}$ Articles $1(\mathrm{~d})$ and 1(e) of the Joint Declaration also made a significant effort to recognise the role of internet intermediaries as mere conduits of third-party content. Intermediaries such as internet service providers should never be subjected to liability for "any third-party content relating to those services" unless they take an active part to edit the content, or "intervene in that content or refuse to obey an order adopted with due

18 The Guardian, "Fake News Images Add Fuel to Fire in Myanmar, after More than 400 Deaths," The Guardian, 2017, https://www.theguardian.com/global-development/2017/sep/05/fakenews-images-add-fuel-to-fire-in-myanmar-after-more-than-400-deaths.

19 See Article 19(3) of the ICCPR and Johannesburg Principles. 
process guarantees by an independent, impartial, authoritative oversight body (such as a court) to remove it". This is in line with many of the practices in the United States, European Union, OECD, and Asian countries including Malaysia to grant immunity to intermediaries that merely act as conduits of information. ${ }^{20}$ Some models of safe harbours such as the EU E-Commerce Directive 2000 and the US Digital Millennium Copyright Act 1998 granted complete immunity to intermediaries from legal actions where third-party content is hosted on their platforms subject to fulfillment of prescribed conditions.

On the other hand, the condition to limit restrictions to freedom of expression strictly for necessary and justifiable grounds can be seen in Article 1(f) whereby the Joint Declaration dedicated one provision to put its thoughts on state-mandated blocking of the entire website. Internet filters are the most common tool developed to restrict access to targeted categories of content, usually illegal in nature. ${ }^{21}$ Article 2 of the Joint Declaration provides that "general

20 Lilian Edwards, "The Role and Responsibility of Internet Intermediaries in the Field of Copyright and Related Rights," 2011, http://www.wipo.int/copyright/en/doc/role_and_responsibility_of_the_in ternet_intermediaries_final.pdf.

21 The UN Special Rapporteur on the promotion and protection of the right to freedom of opinion and expression, Mr. Frank La Rue explained Internet filtering as:- "...measures taken to prevent certain content from reaching an end user. This includes preventing users from accessing specific websites, Internet Protocol (IP) addresses, domain name extensions, the taking down of websites from the web server where they are hosted, or using filtering technologies to exclude pages containing keywords or other specific content from appearing." The process to filter Internet content was described by Australian Communications and Media Authority (ACMA) as involving "...the use of computer or software to screen content and control users' access to that content ... deemed objectionable or that falls into certain predetermined categories of content deemed to be inappropriate for a given user" Australian Communications and Media Authority, "Developments in Internet Filtering Technologies and Other Measures for Promoting Online Safety" (Melbourne, 2008), http://www.acma.gov.au/webwr/_assets/main/lib310554/developments_i $\mathrm{n}$ _internet_filters_1streport.pdf.. Internet filtering has potential to mitigate risks of exposure to content risks online, particularly child pornography, adult pornography, violence, and hate speech. Julian J. 
prohibitions on the dissemination of information based on vague and ambiguous ideas, including, "false news" or "non-objective information", are incompatible with international standards for restrictions on freedom of expression, as set out in paragraph 1(a), and should be abolished". Further, "State actors should, in accordance with their domestic and international legal obligations and their public duties, take care to ensure that they disseminate reliable and trustworthy information, including about matters of public interest, such as the economy, public health, security and the environment".

On the other hand, Article 4 of the Joint Declaration gave an alternative to internet intermediaries, in cases where they intend to remove, alter or moderate third party content on their platforms. It provides that "they should adopt clear, predetermined policies governing those actions. Those policies should be based on objectively justifiable criteria rather than ideological or political goals and should, where possible, be adopted after consultation with their users". Article 4 implies that the removal process of third-party content cannot be done automatically by internet intermediaries. Content creators need to be consulted before the takedown or blocking mechanism took place.

Dooley et al., "Review of Existing Australian and International CyberSafety Research" (Australia, 2009), http://www.google.com.my/url?sa=t\&rct=j\&q=\&esrc=s\&source=web\&c $\mathrm{d}=1 \& \mathrm{cad}=\mathrm{rja} \&$ uact $=8 \& \mathrm{ved}=0 \mathrm{CCkQFjAA} \& u r l=\mathrm{http}: / / \mathrm{www}$. communicat ions.gov.au/_data/assets/pdf_file/0004/119416/ECU_Review_of_existi ng_Australian_and_international_cybersafety_research.pdf\&ei=aAlzU6DvBMeiugSKpYDIBw\&usg=AFQjCN EL0oxgsWlo7XN8ZoRUNipMhXtAZQ\&bvm=bv.66699033,d.c2E..

This explains why Internet filters have been seriously developed in mid1990s, particularly to regulate children's access to illegal and harmful materials online. Australian Communications and Media Authority, "Developments in Internet Filtering Technologies and Other Measures for Promoting Online Safety"; Jack Balkin, "Digital Speech and Democratic Culture: A Theory of Freedom of Expression for the Information Society," New York University Law Review 1, no. 1 (2004), http://digitalcommons.law.yale.edu/fss_papers/240; Jack Balkin, Beth Simone Noveck, and Kermit Roosevelt, "Filtering the Internet: A Best Practices Model," Information Society Project at Yale Law School, 1999, http://www.yale.edu/lawweb/jbalkin/articles/Filters0208.pdf. 
In this regard, it is important for this paper to analyse how the above legal principles were put to practice particularly by platform providers. On that note, the next section examines popular social media platforms on how their Terms of Use were designed to address the regulation of fake news, and to what extent such Terms of Use have adopted the principles laid down in the Joint Declaration, as seen in the following section.

\section{SOCIAL MEDIA PLATFORMS: ADOPTING THE JOINT DECLARATION VIA CONTRACTUAL RELATIONS}

The 2016's United States Presidential Election campaigns have been surrounded by gossip and wild speculations that may have affected how the results turned out. ${ }^{22}$ In response to the said problem, dominant social media companies started to develop policies and terms of use purportedly designed to combat the spread of fake news and its intended effects. As will be seen in the analyses below, social media platforms have adopted the principles of the Joint Declaration in their respective Terms of Use. All platform users must agree to the respective Terms of Use prior to using the services and failure to adhere to the agreed terms may result in serious consequences. The paper analysed Facebook's Statement of Rights and Responsibilities, followed by other social media operators as follows:

\section{Facebook}

Facebook was founded in the United States in 2004 by Mark Zuckerberg where it is used "to stay connected with friends and family, to discover what's going on in the world, and to share and express what matters to them". ${ }^{23}$ Facebook allows users to share ideas and information in the forms of videos, songs, images, chats, documents, and more. Facebook's Statement of Rights and

22 Hunt Allcott and Matthew Gentzkow, "Social Media and Fake News in the 2016 Election," Journal of Economic Perspectives 31, no. 2 (2017): 211-36, https://doi.org/10.1257/jep.31.2.211.

23 Facebook, "About," Facebook, 2014, https://www.facebook.com/facebook/info. 
Responsibilities $^{24}$ acts as codes of conduct applicable to Facebook users. Contrary to YouTube's Community Guidelines, Facebook's Statement of Rights and Responsibilities is written in simple language to describe information on user's protections when surfing its webpage.

Article 2 of the Facebook Statement of Rights and Responsibilities excludes itself from any liability over content shared or uploaded by its users onto its pages. This is in line with the 'safe harbour' protection accorded to internet intermediaries in the US Digital Millennium Copyright Act 1998. However, its users are provided with options to control the amount of information shared by them to certain levels of the audience on Facebook. At the same time, Article 2 (1) grants Facebook a non-exclusive, transferable, sublicensable, royalty-free, worldwide license to use any internet content that users share on Facebook sites. This privilege ends when users delete such content or delete their Facebook accounts. Nevertheless, if such content has been shared to others (and that other users further share such content with another user), the privilege Facebook has on such content continues to exist.

Facebook's Statement of Rights provides general policies on safety issues while surfing its sites. Realising that it cannot guarantee internet users to be free from cyber threats, Article 3 further imposes duties on Facebook users not to engage into illegal and immoral activities such as posting of unauthorised commercial communications including spam, spreading bots, engage in unlawful multi-level marketing on Facebook, upload viruses, cyberbullying or harassment, and posting of illegal content including pornography, violence, and hate speech.

Facebook further reminds its users not to post content in violation of the law (in particular the US law). If illegal content is found on its pages, Facebook in its Article 5 has full discretion to remove any such content. Nevertheless, if users believed that such removal was done by mistake, Facebook shall provide users with the right to appeal. Should any users infringe on the intellectual property rights of another user on a repeated basis, Facebook will disable such accounts where appropriate. Similar to YouTube, Facebook opts for

24 Facebook, "Statement of Rights and Responsibilities," Facebook, 2013, 2. 
content-removal technology as a measure to protect its users and itself from liabilities.

However, age-verification technology is not applicable on Facebook's website since its Article 4 of the Statement of Rights grants the right to own an account for users thirteen years and above. Users below the age of thirteen cannot register for an account thus cannot have access to Facebook content. Nevertheless, many children below thirteen own their Facebook accounts with false age information provided which violates with Article 4 of the Facebook Statement of Rights. ${ }^{25}$ This marks a challenge not only to Facebook but also to other social media in their effort to reduce children's exposure to content risks online.

Facebook's Community Guidelines stipulate that the company does not condone any act of publishing or sharing of inaccurate, misleading or fake information with the intention to "collect likes, followers or shares". ${ }^{26}$ Facebook has taken serious steps to remove selected profiles that were found to impersonate other people upon complaints and internal investigation. The company used to create a fake news labeling system in 2017 where Facebook users can send alerts so that potentially fake stories may be identified by a third-party fact-checkers. If the third-party fact-checkers found the stories flagged as fake, users who shared it will be sent warnings. However, the system has been criticised by internet users as ineffective because when a story is flagged with a 'disputed' tag, more people were looking for the content hence increasing traffic to the news. ${ }^{27}$

25 Tanya Byron, "Safer Children in a Digital World: The Report of the Byron Review" (Nottingham, 2008), 61, http://webarchive.nationalarchives.gov.uk/20130401151715/http://www. education.gov.uk/publications/eOrderingDownload/DCSF-003342008.pdf.

26 Facebook, "Facebook Community Standard - Misrepresentation," Facebook, 2019 , https://www.facebook.com/communitystandards/misrepresentation; ARTICLE 19, "Side-Stepping Rights: Regulating Speech by Contract" (United Kingdom, 2018), https://www.article19.org/wpcontent/uploads/2018/06/Regulating-speech-by-contract-WEB-v2.pdf.

27 Sam Levin, "Facebook Promised to Tackle Fake News. But the Evidence Shows It's Not Working | Technology | The Guardian," The 
Following this response, Facebook declared that it will no longer detect fake news but instead will prioritise contents published by 'family and friends' or rated as trustworthy by the Facebook community. Article 18 of the Facebook Community Standards provides that it "does not remove false news," but "significantly reduces its distribution by showing it lower in News Feed." To this end, Facebook uses "various signals, including feedback from our community, to inform a machine learning model that predicts which stories may be false". More importantly, the company believes that it is important to empower users to decide "what to read, trust, and share by informing them with more context and promoting news literacy".

\section{YouTube}

YouTube was founded in 2005 in the United States where it allows billions of people to discover, watch, and share user-created videos ${ }^{28}$. Being a Google's subsidiary, YouTube acts as "a forum for people to connect, inform, and inspire others across the globe and acts as a distribution platform for original content creators and advertisers large and small". ${ }^{29}$ YouTube is a User Generated Content (UGC)based website where contents are uploaded or contributed by third party internet users. Contents uploaded are in the forms of videos and songs with varieties of subjects. It is reported that YouTube receives more than 300 hours of user-generated content in one minute, thus making UGC pre-moderation almost impossible. ${ }^{30}$

YouTube's Community Guidelines provide for safeguards and general policies on their legal positions should cyber crimes be committed on their site. For example, should any YouTube user be an owner of a trademark and believes that his trademark has been infringed, YouTube declared that it is not in the position to mediate

Guardian,

2017

https://www.theguardian.com/technology/2017/may/16/facebook-fakenews-tools-not-working.

28 YouTube, “About," Youtube, 2015, https://www.youtube.com/yt/about/.

29 YouTube, "About YouTube," Youtube, 2014, http://www.youtube.com/yt/about/.

30 YouTube, "Statistics," Youtube, 2015, https://www.youtube.com/yt/press/statistics.html. 
trademark disputes between users and trademark owners. The company suggested that such disputes should be resolved directly with the internet user who posted the content in question. To assist this process, YouTube provides an easy mechanism for trademark owners to contact the users through the private messaging feature. In terms of online defamatory content posted on YouTube, YouTube users may visit an online web form where users will be assisted to launch complaints where further investigation shall ensue.

YouTube claimed that they are continuously committed to protecting users from spam, deceptive practices, and scams. In its Community Guidelines, "anything that artificially increases the number of views, likes, comments, or other metrics ... is against our terms". ${ }^{31}$ With regard to harmful or dangerous content, YouTube takes the position to disagree if users share contents intending to incite violence or encourage dangerous activities that have inherent risks of serious physical harm or death unless it is for the purpose of education, documentary, scientific, or artistic and are not gratuitously graphic. However, videos that incite or teach people to commit acts of violence or show minors participating in dangerous activities are strictly prohibited and shall be removed from the site. In this kind of videos, YouTube shall apply age-restriction requirements to ensure viewers are of the legal age to view such videos.

On the other hand, YouTube also realised that it has become a tool for journalists, documentarians, and other users to publish personal and professional events in their lives. Thus, it may be inevitable that some videos may be violent or graphic in nature. Hence, YouTube asked those video uploaders to categorise the video they post and advised that content should be balanced with additional context and information. However, YouTube shall remove any posting found to be gratuitous with no element of contextual or educational in nature. Alternatively, YouTube may age-restrict content to ensure viewers are of the legal age to view such materials. In this regard, YouTube adopts self-regulatory content classification with no element of state involvement. YouTube is also against cyber harassment, cyberbullying, or hate speech and encourages its visitors to lodge reports should they come across such videos. YouTube opts

31 Youtube, "Community Guidelines," Youtube, 2014, http://www.youtube.com/t/community_guidelines. 
for age-restricting and content-removal technologies as measures to protect its viewers against content risks, which are part of their selfregulatory commitments.

YouTube enforces its community guidelines through the 'Community Guidelines Strikes' rules. Any YouTube users may report for violation of its Community Guidelines if they stumble upon illegal and harmful content on YouTube. Upon receiving such a report, a YouTube team shall evaluate whether there has been any breach of its Community Guidelines. If a breach of condition was found, YouTube shall remove the said video and notify the uploader through email reasons for the removal. The uploader shall be given the 'First Strike' that serves as a warning and expires in 6 months. The uploader would receive the 'Second Strike' if there was a second breach of the YouTube Community Guidelines that disables him from uploading new content for two weeks. The uploader may upload new content after the expiry of the two weeks period. However, if the uploader's account receives a 'Third Strike' before the expiry of the 'First Strike' (within 6 months), then his account shall be terminated. There are exceptions to the Community Guidelines strikes rules where the uploader shall not receive 'strikes' if the content is removed (1) for the safety of the uploader; (2) privacy complaints; (3) court order and; (4) other non-malicious issues. ${ }^{32}$ This fact suggests that the YouTube team has a wider discretion to interpret the provisions of YouTube Community Guidelines on a case-by-case basis.

With regard to fake news online, the YouTube Community Guideline does not ban 'fake news' alone but is committed to ensuring that the platform is free from spam, scams, and other deceptive practices. ${ }^{33}$ It has declared that should any users apply misleading metadata, such as misleading tags, titles or thumbnails that intend to boost the number of viewers, these may cause content removal. Market Watch reported that YouTube has been exploring methods to improvise its search algorithm so that it shall invite more

32 YouTube, "Community Guidelines Strikes," YouTube, 2018, https://support.google.com/youtube/answer/2802032?hl=en.

33 YouTube, "Spam, Deceptive Practices \& Scams Policies," Youtube, 2019, https://support.google.com/youtube/answer/2801973. 
authoritative sources but has not disclosed how such methods were implemented. ${ }^{34}$

\section{Google \& Twitter}

On another note, Google and Twitter have prohibited fake news and misinformation. For example, in 2017, Google had banned more than 200 publishers from its advertisement network, AdSense for publishing misinformation. Google has announced that the company is serious to fight fake news and misinformation to help journalism "thrive in the digital age". ${ }^{35}$ On the other hand, Twitter does not clearly ban fake news and misinformation. However, Twitter has stated that it is against impersonation, spam, and bots. Twitter does not wish to become an arbiter of truth, nevertheless, it has taken some positive steps such as to implement a "crackdown on some Russian fake accounts that allegedly interfered in the US election." 36

The next section analyses the national legal framework applicable to Malaysia to regulate fake news. It examines how Malaysia aims to restrict the availability of fake news, through legislation and relevant technical means.

\section{REGULATION OF FAKE NEWS IN MALAYSIA}

Under the Malaysian legal framework, publication and dissemination of fake news are clearly prohibited by three legal instruments. The first would be Sections 211 and 233 of Communications and Multimedia Act 1998 (CMA), which classify 'false content' under broad categories of 'offensive content'. The CMA criminalises the communication of false content against any internet users. Section 233 further criminalises "improper use of network facilities or network services" for the purpose of communication of false content. These two provisions are rather general in nature and shall be cross-

34 Jack Nicas, "YouTube Cracks down on Conspiracies, Fake News," Market Watch, 2017, https://www.marketwatch.com/story/youtubecracks-down-on-conspiracies-fake-news-2017-10-05.

35 ARTICLE 19, "Side-Stepping Rights: Regulating Speech by Contract" (United Kingdom, 2018).

36 ARTICLE 19. 
referred with the industry Content Code, as adopted by Communications and Multimedia Content Forum (CMCF) in 2004. ${ }^{37}$

Article 7.0 of Content Code (the Code) expressly deals with false content online although arguably not in-depth. The Code, which is meant for public and industrial reference was plainly worded for ease of understanding. This explains why the Content Code is not meant to be a statute but a mere self-regulatory industrial guideline. ${ }^{38}$ The Code defines 'false content' as material "likely to mislead, due to amongst others to incomplete information ${ }^{39}$ " where it advises internet users to avoid contents which are unverified and false. Article 7.3 provides for an exception where false content is not prohibited when it is satire, parody, and fictional in nature. It is therefore suggested that 'online speculations' should be defined similarly as false content since speculations are likely to mislead people with unverified information. ${ }^{40}$

Meanwhile, the Anti-Fake News Act 2018 was perhaps one of the hastiest legislations ever enacted in the history of Malaysia. The Bill was tabled on $27^{\text {th }}$ March 2018 and it only took two weeks for it to be debated, passed, and gazetted, i.e. on $11^{\text {th }}$ April 2018. For purposes of interpretation, Section 2 of the Fake News Act 2018 defines 'fake news' as, "any news, information, data, and reports, which is or are wholly or partly false, whether in the form of features, visuals or audio recordings or in any other form capable of suggesting words or ideas". The word 'publication' was also defined to include any written or digitally or electronically produced publication. However, it is unclear whether the meaning of 'publication' under Section 2 has to be read together with Section 114(A) of the Evidence Act 1950 - hence suggesting a lacuna on point. Section 3(1) of the Act grants extra-territorial application whereby any person (regardless of his nationality) may be liable and dealt with as if the offence was

37 See Section 213 (1) and (2) CMA 1998

38 Mahyuddin Daud and Juriah Abd Jalil, "Protecting Children against Exposure to Content Risks Online in Malaysia: Lessons from Australia," Jurnal Komunikasi Malaysian Journal of Communication Jilid 33, no. 1 (2017): 115-26.

39 See Article 7.1 Content Code

40 Mahyuddin Daud, "Wild Speculations on the Missing Flight MH370: Balancing Online Expression and Content Regulation in Malaysia," Malayan Law Journal Articles 3 (2015): cvii. 
committed within Malaysia. Section 3 (2) further extends the jurisdiction of the Act where such a person may be accountable if he publishes fake news concerning Malaysia or Malaysian citizens.

The Anti-Fake News Act 2018 provides categories of offences, which carry a maximum fine of RM500,000 or ten years imprisonment. The Act lacks justification of why such severe punishments were imposed as if it is equivalent to crimes against the state. Section 4 (1) of the Act criminalises any act of "creating, offering, publishing, printing, distributing, circulating, or disseminating any fake news or publication containing fake news". However, one must knowingly commit the said acts in order for him to be found guilty under this provision. If one does not know or is unaware that the information, he shares online is false, then he shall not be guilty of an offence under Section 4 .

The $2^{\text {nd }}$ category provides that anyone who renders financial assistance to facilitate the offence under Section 4, whether directly or indirectly, may also be found guilty under Section 5. Section 6(1) further imposes a duty to remove publication containing fake news and failure to do so amounts to an offence. In this situation, the Sessions Court may order for the removal of any publication containing fake news under Section 7. To facilitate service of court orders, Explanation to Section 7 provides that such service may be made (other than the standard postal services) to the offender's email address or social media account. However, no provisions in the AntiFake News Act 2018 stipulates any specified time for the alleged offender to take down fake news. If cross-reference to the Content Code is made, the prohibited content should be removed within 1 to 24 hours from the time the takedown notice was sent. This suggests that the Content Code was more detailed in its removal procedures so that clear guidance can be provided to remove prohibited content. On the contrary, should anyone receiving such a removal order fail to remove any fake news, Section 9 of the Anti-Fake News Act 2018 empowers the Court to direct the police or the MCMC to take any necessary measures to remove the said publication. However, such measures were not defined or suggested by the Act.

Any person to whom a removal order has been served but believes that the alleged fake publication does not amount to 'fake news' under the Act, may proceed to apply to the court to set aside such order. However, such right is not available for any removal order 
obtained by the government under Section 7. Section 8(3) provides that no application for setting aside of a removal order may be made by any person if it comes from the government. In this regard, it can be foreseen that the government is given a special privilege by the Act to remove such fake news, particularly if it involves issues concerning national security or public interests. To date, no challenge has been made to the court on the constitutionality of this provision.

However, it may be argued that one should have the right to apply to set aside such an order (with sufficient justifications) even if it was obtained by the government under Section 7. The position in Section 8(3) may also form an obstacle to freedom of expression and information, especially in cases where the real intention is to restrict the circulation of the said news was for political or ill motives, other than those which are prejudicial to public order or national security.

In the first month of the Anti-Fake News Act 2018's enforcement, a Danish citizen was prosecuted under the Act for "maliciously publishing fake news in the form of a YouTube video under the user name Salah Sulaiman and was sentenced to a week's jail and fined RM10,000" ${ }^{41}$ After PH won in the $14^{\text {th }} \mathrm{GE}$, the Minister of Information and Communication Technology, Mr. Gobind Singh Deo promised to abolish the newly enacted Anti-Fake News Act 2018. The Act was allegedly enacted as a political weapon to cripple free speech during the election. Further, it was also purportedly designed as a tool for censorship where online intermediaries were put in unwarranted situations of being continuously exposed to criminal liability. ${ }^{42}$ To date, none of the above allegations were found to be true.

The whole 'drama' came to an end on $19^{\text {th }}$ December 2019, after the House of Senate passed the motion to repeal the Act in its second attempt. Deputy Minister Hanipa Maidin said that the repeal was in line with the government's effort to abolish unjust laws and uphold freedom. Available laws were already sufficient and can

41 Tariq, "Danish National First to Be Sentenced under Anti-Fake News Law."

42 ARTICLE 19, "Malaysia: Anti-Fake News Act Should Be Repealed in Its Entirety.” 
simply be amended to suit current needs. ${ }^{43}$ In an interview with the author, MCMC said that no investigations were carried out under the Act as authorities feared that if the repeal went through, investigations and hearings may be disrupted. ${ }^{44}$ However, it is submitted that more time should be granted to the 'infant' Act to allow more discussions to be commenced so that the time spent enacting was not wasted. Certain legal issues or lacuna may be addressed by simply amending or consolidating the Act, leaving out the need to abolish it.

From the above discussion, it can be established that the law in Malaysia strongly prohibits the dissemination of fake news online. This is also in line with approaches taken by the United Nations Joint Declaration on Freedom of Expression and 'Fake News', Disinformation and Propaganda, and other related legal frameworks as discussed above. It is submitted that Malaysia has four layers of legislative protections to combat fake news, both at the international and national levels. However, the legal framework alone is arguably ineffective to reduce or resolve the problem, as more cases were reported on a daily basis.

\section{ANALYSIS AND CONCLUDING REMARKS}

In essence, it is safe to concur that governments around the world are making comprehensive efforts to identify and address issues surrounding fake news, propaganda, and disinformation. These are not merely dilemmas for those in academia or journalism to tackle. Under the principles outlined in Article 19 of the UN's 1948 Universal Declaration of Human Rights, it requires collective efforts if one wishes to become a responsible self-governor of human rights. Huff argues that the Joint Declaration is an appropriate legal tool to balance intermediary efforts of censorship and control. At the same time, the digital expression must be promoted to ensure open, transparent, unrestricted, factually supported public debate and

\footnotetext{
43 Bernama, "Dewan Negara Passes Repeal of Anti-Fake News Act," BERNAMA, 2019, http://bernama.com/en/news.php?id=1801184.

44 Malaysian Communications and Multimedia Commission. "Interview on the Enactment of Anti-Fake News Act 2018," Interview by Mahyuddin Daud, Putrajaya, July 19, 2019.
} 
didactic discourse as the best ways to confront and counter the most recent incarnations of a seemingly ceaseless information war. ${ }^{45}$

Despite the setting of both international and national legal frameworks that aim to prohibit the publication and dissemination of fake news, it is disturbing to note that fake news remains to be a global problem. Notwithstanding efforts made by the Malaysian government to enact the Anti-Fake News Act 2018 and the Communications and Multimedia Act 1998, fake news continues to be visible and readable particularly on social media. The previous BN government took the initiative to censor illegal content by the MSC Bill of Guarantee No.3 and Section 3(3) of the Communications and Multimedia Act 1998. However, the problem was that the censorship mechanism was not properly developed and transparent, leading to criticisms that the previous government was denying freedom of expression and information.

Nevertheless, the PH government who won the $14^{\text {th }}$ GE also faced a problem of fake news, where the gun was then pointed towards them. As of the date of writing this article, neither the $\mathrm{PH}$ government nor the current Perikatan Nasional government has made any move towards internet censorship, perhaps to honor the electoral promises made to uphold freedom of expression and media. However, with fake news being a global threat, it is submitted that the status quo cannot withstand for long. Affirmative action needs to be taken in order to face issues and challenges posed by fake news and that could start with internet censorship or classification. ${ }^{46}$

45 Mickey Huff, ""Joint Declaration on Freedom of Expression and 'Fake News,' Disinformation, and Propaganda," Secrecy and Society 1, no. 2 (2018),

https://scholarworks.sjsu.edu/cgi/viewcontent.cgi?referer=https://www.g oogle.com.my/\&httpsredir $=1 \&$ article $=1037 \&$ context=secrecyandsociety

46 Daud and Jalil, "Protecting Children against Exposure to Content Risks Online in Malaysia: Lessons from Australia." 